\title{
Otizm Spektrum Bozukluğu Olan Çocuklarda Beslenme Durumunun Belirlenmesi
}

\author{
Determination of Nutritistional Status in Children with Autism Spectrum Disorder
}

\author{
Ayșe Nur KAYNAR ${ }^{1}$, Hande ÖNGÜN YILMAZ ${ }^{2}$
}

\section{ÖZ}

Otizm Spektrum Bozukluğu (OSB), sosyal, iletişim, davranış ve bilişsel becerilerinde sorunlar ile erken çocukluk döneminde ortaya çıkan ve genelde etkilerini yaşam boyu sürdüren, nedeni ve tedavisi halen bilinmeyen nörogelişimsel bir bozukluktur. $\mathrm{Bu}$ araştırmada amaç otizmli çocukların beslenme durumlarını, alışkanlıklarını ve yeme problemlerini belirlemektir. Tanımlayıcı ve kesitsel tipte yapılan bu araştırma, Bağcılar Lokman Hekim Özel Eğitim ve Uygulama Merkezi'nde eğitim gören, 7-14 yaş aras1, $10 \mathrm{k1z} 48$ erkek, toplam 58 çocuk ile gerçekleştirilmiştir. Araştırmada çocuk ve aileye ilişkin genel bilgiler, üç günlük besin tüketim kaydı ve besin tüketim sıklığ1 anketleri uygulanmıştır. Veriler değerlendirildiğinde, çocuklarda sindirim sistemi problemlerinden kabızlık ile şişkinlik ve gaz problemlerinin sık görüldüğü, yeni yiyecek denemeyi reddetmenin de yaygın olduğu görülmüştür. Ayrıca otizmi olan çocukların yiyecekleri renk, tat ve koku özelliklerine göre de tercih ettiği belirlenmiştir. BKI (Beden Kitle İndeksi) ile yiyecekleri renk, tat, koku özelliklerine göre tercih etme ve BKİ ile yeni yiyecek denemeyi reddetme arasında anlamlı ilişki olduğu bulunmuştur $(\mathrm{p}<0,05)$. Besin tüketim sıklığ incelendiğinde süt, kefir, balık, yeşil yapraklı sebzeler, kuru meyveler ve tam tahıllı ekmek gibi besinlerin hiç tüketilmediği görülmüştür. Üç günlük besin tüketim kayıtlarına göre günlük protein alımının fazla olduğu, posa, vitamin B1, B6, folat, kalsiyum ve potasyum alımlarının yetersiz olduğu görülmüştür. Bu çalışmanın sonucuna göre risk altında olan otizmli çocukların beslenme durumları ile beslenme alışkanlıkları takip edilmeli, yaygın görülen gastrointestinal sorunlar tedavi edilmeli, vitamin ve mineral yetersizlikleri önlenmeli ve takıntılı yeme davranışları için çözüm yolları üretilmelidir.

Anahtar kelimeler: Otizm, Otizm spektrum bozukluğu, Beslenme

\section{ABSTRACT}

Autism Spectrum Disorder (ASD), is a neurodevelopmental disorder of early childhood occuring with problems in social, communication, behavioral and cognitive skills and its effects are still unknown throughout the life. The aim of this study is to determine the eating habits and eatings problems of children with autism. This descriptive study was carried out with 58 children, 10 girls and 48 boys, aged 7-14 years, who were educated at Bağcılar Lokman Hekim Special Education and Application Center. In this study, general information about the child and the family, theree day food consumption record and food consumption frequency surveys applied. When the data were evaluated, it was seen that constipation, swelling and gas problems were common in children and problems of trying new food were common. In addition, it is determined that these children prefer foods according to their color, taste and smell characteristics. . There was a significant relationship between BMI (Body Mass Index) and food preference according a color, taste and smellcharacteristics $(p<0,05)$. There was a significant relationship between BMI and refusal to try new food $(p<0,05)$. When the frequency of food consumption is examined, it is seen that foods such as milk, kefir, fish, green leafy vegetables, dried fruits and whole-grain bread have never been consumed. It was observed that daily intake of protein was higher compared to three-day food consumption records, and that the intake of pulp, vitamin B1, B6, folate, calcium and potassium was insufficient. According to the results of this study, nutritional status and nutritional habits of these children at risk should be monitored, gastrointestinal problems should be treated, vitamin and mineral deficiencies should be prevented and solutions should be produced for obsessive eating behaviors.

Keywords: Autism, Autism spectrum disorder, Nutrition

\footnotetext{
*Bu araştırma Ístanbul Okan Üniversitesi Sağlık Bilimleri Enstitüsü tarafindan Dr Öğretim Üyesi Hande Öngün Yılmaz’ın danışmanlı̆̆ında yüksek lisans tezi olarak kabul edilmiştir. Okan Üniversitesi 19.02.2018 tarihli Etik Kurul Kararl ve 12.03.2018 tarihli 59090411-20-E-5275745 sayılı İstanbul Valilik Onayı alındıktan sonra başlanmıştır.

${ }^{1}$ Uzman Diyetisyen, ORCID: 0000-0001-5592-3935

${ }^{2}$ Dr. Öğr.Üyesi, Okan Üniversitesi, Sağlık Bilimleri Sağlık Bilimleri Fakültesi, Beslenme ve Diyetetik Bölümü, ORCID:0000-0002-3497-567X 


\section{GİRISS}

Otizm spektrum bozukluğu (OSB); belirtileri erken çocukluk döneminde görülmeye başlayan ve etkileri genellikle yaşam boyu süren, sosyal, iletişim ve davranış becerilerinde sorunlara yol açan nörogelişimsel bir bozukluktur. ${ }^{1}$

Bugünkü anlamı ile otizm ilk kez 1943 yılında Leo Kanner tarafindan; "duygusal bağın otistik bozukluğu" olarak tanımlanmıştır. ${ }^{2} 1944$ yılında ise Hans Asperger otizmin sosyal etkileşim ve ilgi alanları sınırlı olan, yüksek zekaya sahip erkek çocuklarda görülen bir bozukluk olduğunu ileri sürmüştür. ${ }^{3}$ 1980'de Amerikan Psikiyatri Birliği (APA) tarafindan yayınlanan Mental Bozuklukların Tanısal ve Sayımsal El Kitabı-III'de (DSM) otizm ilk defa ayrı bir kategoride tanımlanmıştır. 1994 yılında DSM-IV'de otizm daha kapsamlı bir şekilde tanımlanmış ve bu durum vakalarda artışa sebep olmuştur. ${ }^{4}$

Amerikan Hastalıkları Kontrol ve Önleme Merkezi (CDC) verilerine göre, OSB görülme s1klığ 2000 yılında 1/150 iken, 2014 yılında $1 / 59$ olduğu tahmin edilmektedir. ${ }^{5}$

Otizm etiyolojisi henüz bilinmemekle birlikte genetik, beyin işlevleri, nörokimyasal ve immünolojik etkenler araştırılmaktadır. ${ }^{6}$

OSB'li çocukların üçte birinde gastroözofageal reflü (GÖR), abdominal ağr1, diyare ve kabızlık gibi gastrointestinal sorunlar bildirilmiştir. ${ }^{7}$ Ayrıca otizmli çocuklarda olağandışı bir ağız kokusu ve tat hassasiyeti de bildirilmiştir. ${ }^{8}$

Otizmli çocuklardaki gastrointestinal sorunlar, vitamin ve mineral dengesini olumsuz yönde etkilemektedir. Rafine gıdaların aşırı tüketilmesi de vitamin ve mineral eksikliklerine sebep olmaktadır. ${ }^{9}$

OSB'li çocuklarda kan, saç ve diğer dokularda magnezyum, çinko, selenyum, A vitamini, B kompleks vitaminleri, D vitamini, E vitamini ve karnitin daha düşük düzeylerde bulunmuştur. ${ }^{10}$

Bazı vitaminlerin kan seviyeleri normal olsa bile o vitamini takviye etmenin otizmli çocuklara fayda sağlayabileceği düşünülmektedir. ${ }^{9}$

$\mathrm{Bu}$ yapılan çalışmalar OSB'yi tedavide besinleri ve besin takviyelerinin etkinliğini belirlemek için müdahale çalışmalarına yol göstermiştir. ${ }^{10}$

Otizmin tedavisinde vitamin ve mineral takviyeleri dışında diyet tedavisi de yaygın olarak kullanılmaktadır. Otizmde glutensiz ve kazeinsiz diyetin (GFCF) kullanılması ilk olarak Reichelt ve arkadaşları tarafından gluten ve kazein peptidlerinin otizm bozukluğunun patogenezinde etiyolojik bir role sahip olduğu görüşüyle ortaya çıkmıştır. ${ }^{11}$ Bu ortaya çıkan teori "Opioid Excess Theory" olarak adlandırılır ve gluten ve kazein gibi proteinlerin yeterince parçalanamaması sonucu oluşan bazı peptidlerin sistemik dolaşıma geçmesiyle opioid gibi davrandığ görüşüne dayanmaktadır. ${ }^{12,13}$ Opioid peptidlerin OSB'li çocuklarda görülen bağırsak geçirgenliği sebebiyle kan dolaşımına girmesi ve kan-beyin bariyerini aşması sonucu merkezi sinir sistemini etkilediği düşünülmektedir. Ancak bu konuda yapılan çalışmaların sınırlılığ 1 sebebiyle kesin bir sonuca varmak mümkün değildir. ${ }^{14,15}$

Yaygın uygulanan bir diyet türü ketojenik diyettir (KD). KD'nin OSB üzerindeki etki mekanizmasının glukozun azaltılması yoluyla ağrı duyarlılığının azalabileceği ve antiinflamatuar özelliklere sahip olabileceği yönündedir. ${ }^{16}$

OSB'li çocukların beslenme durumlarını etkileyen birçok faktör bulunmaktadır. T1bbi/nütrisyonel faktörler; gastrointestinal problemler, besin alerjileri, metabolik anomaliler ve daha önceden mevcut olan besin eksiklikleri, davranışsal/bağlamsal faktörler ise sorunlu yeme davranışı, duyusal işleme güçlükleri ve aile faktörleridir. ${ }^{17}$

Otizmli çocukların yaklaşık \%80'i besin seçici olarak tanımlanmaktadır. ${ }^{13} \mathrm{Bu}$ durum OSB'nin özelliği olan rutin ve ritüellere bağl1 olma, aşırı hassasiyet ve duyusal uyum problemlerine bağlı olabilmektedir. ${ }^{18}$ 
Otizmli çocukların beslenme durumları ile beslenme alışkanlıklarının belirlenmesi ve sık görülen kabızlık, gastrointestinal semptomlar, vitamin ve mineral yetersizliklerini önlemek OSB'nin karmaşıklığını yönetmek için önem arz etmektedir. Bu araştırmanın amacı otizmli çocukların beslenme durumlarını, alışkanlıklarını ve yeme problemlerini belirlemektir.

\section{MATERYAL VE METOT}

\section{Araştırmanın Tipi, Evren ve Örneklemi}

Tanımlayıc1- Kesitsel tipte planlanmış olan bu araştırma Mart-Nisan 2018 tarihlerinde, İstanbul'da yalnızca 2 tane bulunan Otizmli Çocuklar Eğitim Merkezi'nden (OÇEM) biri olan Bağcılar Lokman Hekim Özel Eğitim ve Uygulama Merkezi'nde eğitim gören otizmli çocukların aileleri ile yapılmıştır. $\mathrm{Bu}$ araştırmanın örneklemini, bu okulda eğitim gören öğrencilerin, araştırmaya katılmayı kabul eden ebeveynleri oluşturmaktadır. Toplamda 58 öğrencinin anne-babaları araştırmaya katılmayı kabul etmişlerdir. Türkiye 'de otizmin görülme sıklığı ile ilgili bir çalışma bulunmamakla birlikte her 68 doğumda bir çocuğu etkilediği tahmin edilmektedir. Otizmin görülme siklığ ve örneklem hesab1 göz önünde bulundurulduğunda örneklem sayısı yeterli bulunmuștur.

\section{Araștırmanın Etik Yönü}

Araştırmaya Okan Üniversitesi 19.02.2018 tarihli Etik Kurul Kararı ve 12.03.2018 tarihli 59090411-20-E-5275745 say1l İstanbul Valilik Onayı alındıktan sonra başlanmıştır. Araştırma gönüllülük esasına bağlı olup katılımcılara "Veli İzin Formu" dağıtılmıştır.

\section{Veri Toplama Aracı}

Araştırmada veri toplama aracı olarak araştırmacı tarafından ilgili literatür doğrultusunda hazırlanmış olan "Anket Formu" kullanılmış olup anket formu araştırmacı tarafından yüz yüze görüşme tekniği ile uygulanmıștır. Uygulanan anket formu "Çocuğa İlişkin Bilgiler", "Aileye İlişkin Bilgiler", "Besin Tüketim Sıklığı" ile "3 Günlük Besin Tüketim Kaydı" bölümlerinden oluşmaktadır. "Çocuğa İlişkin Bilgiler" bölümünde çocuğun yaşı, ağırlığ1, boyu, tanı aldığ yaş, uyguladığ 1 diyetler, tanı konulmuş hastalıkları ve yemek yeme ile ilgili davranışları, "Aileye İlişkin Bilgiler" bölümünde anne ve babanın sosyodemografik özellikleri belirlenmiștir. Ağırlık ve boy araștırmacı tarafından ölçülmüș olup, BKI (Beden Kitle İndeksi) ve BKİ Z skoru ve BKİ persentil hesaplanmıștır. Ağırlık ölçümü için standart 100 g'a kadar hassas kapasiteye sahip tartı kullanılmıştır. Çocuğun beslenme durumunun belirlenmesi için besin tüketim sıklığı ve 2 gün hafta içi 1 gün hafta sonu olmak üzere 3 günlük besin tüketim kayıtları alınmıştır. Enerji ve besin ögelerinin hesaplanmasinda BeBİS (Beslenme Bilgi Sistemi) kullanılmıștır.

\section{Verilerin Analizi}

İstatistiksel analiz için SPSS 21.0 (Statistical Package for the Social Sciences) paket programı kullanılmıştır. Değişkenleri tanımlamada ortalama (x), standart sapma (sd), minimum-maksimum (min.-max.), say1 (n) ve yüzde (\%) kullanılmıştır. Normalliğin belirlenmesinde Kolmogorov Smirnov testi kullanılmıştır. Normal dağılan verilerin analizinde Independent Samples $\mathrm{T}$ Test, normal dağılmayan verilerin analizinde Mann Whitney U testi kullanılmıștır. İstatistiksel anlamlılık düzeyi olarak $\mathrm{p}<0,05$ kabul edilmiştir.

\section{Araștırmanın Kısıtlılıkları}

Örneklem sayısının düşük olması, tek bir özel eğitim merkezinde yapılmıș olması ve ailelerden sözlü iletişim yoluyla bilgi alınmış olmasıdir. 


\section{BULGULAR VE TARTIȘMA}

$\mathrm{Bu}$ araştırma İstanbul Bağcılar Lokman Hekim Özel Eğitim ve Uygulama Merkezi'nde eğitim gören 7 ila 14 yaş arası 58 çocuğun ebeveynleri ile yapılmıştır. Çocukların cinsiyet dağılımı incelendiğinde 10 kız 48 erkek olduğu görülmüştür. OSB'nin, erkek çocuklarda kız çocuklardan 4 kat daha fazla görüldüğü bilinmektedir. ${ }^{19,20} \mathrm{Bu}$ araştırmada da benzer durum görülmüştür.

Katılımciların \%17,2' si k1z iken \%82,8' i erkektir. Çocukların yaş ortalaması $10,76 \pm 2,33$ yıldır. Çocuklarda en yaygın görülen hastalığın \%12,1 ile epilepsi olduğu belirlenmiştir. Ebeveynlerin \%22,4'ü özel diyet uyguladıklarını belirtmiştir. GF (Glütensiz) diyet uygulayanlar \%8,6, GFCF diyeti uygulayanlar \%10,4, GAPS (Bağırsak ve Psikoloji Sendromu) diyeti uygulayanlar $\% 1,7, \quad \mathrm{KD}$ uygulayanlar $\% 1,7$ olarak bulunmuştur.

Tablo 1. Çocuklara İlişkin Genel Bilgiler

\begin{tabular}{|c|c|c|}
\hline & $\mathbf{n}$ & $\%$ \\
\hline \multicolumn{3}{|l|}{ Cinsiyet } \\
\hline $\mathrm{K} 1 \mathrm{Z}$ & 10 & 17,2 \\
\hline Erkek & 48 & 82,8 \\
\hline \multicolumn{3}{|l|}{ Tanı konulmus hastalık } \\
\hline Epilepsi & 7 & 12,1 \\
\hline Mental retardasyon & 2 & 3,4 \\
\hline Hipotroid & 2 & 3,4 \\
\hline \multicolumn{3}{|l|}{ Özel diyet uygulama } \\
\hline Evet & 13 & 22,4 \\
\hline Hayır & 45 & 77,6 \\
\hline \multicolumn{3}{|l|}{ Uygulanan diyet } \\
\hline Glutensiz diyet & 5 & 8,6 \\
\hline Glutensiz ve kazeinsiz diyet & 6 & 10,4 \\
\hline GAPS diyeti & 1 & 1,7 \\
\hline Ketojenik diyet & 1 & 1,7 \\
\hline \multicolumn{3}{|l|}{ Sindirim sistemi problemleri } \\
\hline Konstipasyon & 21 & 38,0 \\
\hline Diyare & 2 & 3,6 \\
\hline Şişkinlik ve gaz & 17 & 30,7 \\
\hline \multicolumn{3}{|l|}{ Yeme problemleri } \\
\hline Çiğneme güçlüğü & 4 & 6,6 \\
\hline Besinleri ağızda tutma & 5 & 8,2 \\
\hline Yeni yiyecek denemeyi red & 28 & 46,4 \\
\hline Verilen besini geri çıkarma & 5 & 8,2 \\
\hline \multicolumn{3}{|c|}{$\begin{array}{l}\text { Yiyecekleri özelliklerine göre } \\
\text { tercih etme durumu }\end{array}$} \\
\hline Renk & 17 & 22,3 \\
\hline Tat & 11 & 14,6 \\
\hline Koku & 31 & 40,8 \\
\hline \multicolumn{3}{|c|}{ Kendi başına yemek yiyebilme } \\
\hline Evet & 43 & 74,1 \\
\hline Hayır & 15 & 25,9 \\
\hline
\end{tabular}

Çocuklarda görülen en yaygın sindirim problemleri sirasiyla \%38,0 kabızlık, \%30,7 şişkinlik ve gaz, \%3,6 ishaldir. Ebeveynlerin $\% 55,2$ 'si çocuklarında yemek yeme problemlerinden en az birinin olduğunu bildirmişlerdir. En yaygın görülen yemek yeme problemi \%46,4 oranında yeni yiyecek denemeyi reddetme olmuştur. Ebeveynlerin $\% 75,9$ 'u çocuklarının yiyecekleri renk, tat, koku özelliklerine göre tercih ettiklerini belirtmişlerdir. Çocukların \%75,1'i kendi başına yemek yiyebiliyorken \%25,9'unun kendi başına yiyemediği tespit edilmiştir. Çocukların tükettikleri günlük ögün sayısı ortalama $3,3 \pm 0,8$ ögün iken su miktarı ortalama $1,6 \pm 0,8$ litredir.

Çalışmaya katılan çocukların annelerinin yaş ortalaması $38,7 \pm 5,6$ y1l iken babalarının yaş ortalaması $40,1 \pm 9,7$ yıl olduğu belirlenmiştir. Annelerin eğitim durumları incelendiğinde, \%10,3'ünün okuryazar, \%58,6'sinın ilkokul mezunu, \%19'unun ortaokul mezunu, \%12,1'inin lise mezunu olduğu bulunmuştur. Babaların eğitim durumu incelendiğinde, \%6,9'unun okuryazar, \%43,1'inin ilkokul mezunu, $\% 15,5$ 'inin ortaokul mezunu, \%24,1'inin lise mezunu, \%6,9'unun yüksekokul mezunu olduğu görülmüştür. Annelerin \%89,7'si ev hanımı iken, \%6,9'u işçi, \%1,7'si emekli ve $\% 1,7$ 'sinin ise çalışmiyor olduğu belirlenmiştir. Babaların \%48,3'ü işçi, \%34,5'i serbest meslek, \%5,2'si emekli iken $\% 8,6$ 'sının çalışmıyor olduğu görülmüştür.

Çocukların antropometrik ölçümleri tablo 2 de verilmiştir. Ağırlık ortalaması 47,0 kg, boy ortalamas $140,8 \mathrm{~cm}$, BKİ ortalamas 123,6 $\mathrm{kg} / \mathrm{m}^{2}$, BKİ Z skor ortalamas 1 1,4 ve BKİ persentil ortalaması 86,7 bulunmuştur.

Tablo 2: Çocukların Antropometrik Ölçümleri

\begin{tabular}{lcccc}
\hline & $\mathbf{x}$ & SD & Min & Max \\
\hline Ă̆ırlık (kg) & 47,0 & 15,1 & 22,0 & 90,0 \\
Boy (cm) & 140,8 & 19,8 & 102,0 & 176,0 \\
BKİ (kg/m $\left.{ }^{2}\right)$ & 23,6 & 5,2 & 15,2 & 38,9 \\
BKİ(Z skor) & 1,4 & 1,2 & -2 & 3 \\
BKİ(persentil) & 86,7 & 22,8 & 15,0 & 99,0 \\
\hline
\end{tabular}


Çocukların BKİ persentil değerleri incelendiğinde \%5,2 zayıf, \%12,1 normal, $\% 25,9$ hafif şişman, \%56,9 şişman olduğu belirlenmiştir.

Tablo 3 incelendiğinde BKİ ile konstipasyon problemi ve BKİ ile kendi başına yemek yiyebilme arasında istatistiksel olarak anlamlı bir ilişki bulunamamıştır $(p>0,05)$. BKİ ile şişkinlik ve gaz problemi karşılaştırıldığında, şişkinlik ve gaz problemi yaşayan çocukların BKI'lerinin istatistiksel olarak anlamlı derecede daha yüksek olduğu bulunmuştur $(p=0,046)$. BKİ ile yeni yiyecek denemeyi reddetme durumu karşılaştırıldığında, yeni yiyecek denemeyi reddeden çocukların BKI'leri istatistiksel olarak anlamlı derecede daha düşük olduğu görülmüştür $(p=0,013)$. BKİ ile yiyecekleri renk, tat ve koku özelliklerine göre tercih etme durumu karşılaştırıldığında, yiyecekleri renk, tat ve koku özelliklerine göre tercih eden çocukların BKI'leri istatistiksel olarak anlamlı düzeyde daha düşük olduğu belirlenmiştir $(\mathrm{p}=0,019)$.

Tablo 3: BKİ $\left(\mathrm{kg} / \mathrm{m}^{2}\right)$ ile Beslenmeye İlişkin Alışkanlıklarının Karşılaştırılması

\begin{tabular}{|c|c|c|c|c|c|}
\hline \multicolumn{6}{|c|}{ BKI } \\
\hline & & $\mathbf{n}$ & $\mathbf{X}$ & SD & $\mathbf{P}$ \\
\hline \multirow[t]{2}{*}{ Kabızlık } & Evet & 21 & 23,3 & 4,0 & $0,903^{*}$ \\
\hline & Hayır & 37 & 23,8 & 5,8 & \\
\hline \multirow[t]{2}{*}{ Şişkinlik ve Gaz } & Evet & 17 & 25,1 & 4,6 & $0,046^{*}$ \\
\hline & Hayır & 41 & 23,0 & 5,3 & \\
\hline \multirow{2}{*}{$\begin{array}{l}\text { Kendi Başına Yemek } \\
\text { Yiyebilme }\end{array}$} & Evet & 43 & 23,8 & 5,8 & $0,852 *$ \\
\hline & Hayır & 15 & 23,1 & 2,6 & \\
\hline \multirow{2}{*}{$\begin{array}{l}\text { Yeni Yiyecek Denemeyi } \\
\text { Reddetme }\end{array}$} & Evet & 32 & 23,3 & 3,9 & $0,013 * *$ \\
\hline & Hayır & 26 & 24,1 & 6,5 & \\
\hline \multirow{2}{*}{$\begin{array}{l}\text { Yiyecekleri Renk Tat Koku } \\
\text { Özelliklerine Göre Tercih }\end{array}$} & Evet & 44 & 23,1 & 4,4 & $0,019 * *$ \\
\hline & Hayır & 14 & 25,2 & 7,1 & \\
\hline
\end{tabular}

*Independent T Test **Mann Whitney $U$

Recommended Daily Allowance (RDA) protein alımını 7-8 yaş için $19 \mathrm{~g} / \mathrm{gün}, 9-13$ yaş için $34 \mathrm{~g} /$ gün ve 14 yaş için erkek çocukları 52 g/gün iken kız çocukları için 46 g/gün olarak önermiştir. Tablo 4 incelendiğinde protein alımları önerilen miktarlardan daha fazla olduğu görülmüştür. RDA'ya göre önerilen posa alımı 7-8 yaş için $25 \mathrm{~g} /$ gün, 9-13 yaş için erkek çocukları $31 \mathrm{~g} / \mathrm{gün}, \mathrm{k} 1 \mathrm{z}$ çocukları 26 gr/gün, 14 yaş için erkek çocukları $38 \mathrm{~g} / g u ̈ n$ kız çocukları $26 \mathrm{~g} /$ gün olarak belirlenmiştir. Çocukların günlük aldığı posa miktarı incelendiğinde önerilen miktarları karş1lamadığ1 görülmüştür. Tablo 5 'de vitamin alımlarına bakıldığında yetersiz alınan vitaminlerin folat, vitamin B6 ve vitamin $\mathrm{B} 1$ olduğu görülmüştür. RDA' ya göre yeterli alım miktarları incelendiğinde en yetersiz alım miktarının 14 yaş grubunda olduğu belirlenmiştir. Çocukların mineral alımları incelendiğinde ise kalsiyum alımlarının tüm yaş gruplarında RDA' nın önerdiği miktarlardan çok daha düşük alındığ1 belirlenmiştir. Magnezyum, fosfor, demir, çinko ve potasyum alımlarında da yetersizlik görülmüştür. Tablo 6 incelendiğinde süt tüketenlerin \%29,3'ü her gün, \%8,6'sı haftada 5-6 kez, \%8,6's1 haftada 3-4 kez, \%12,1'i haftada 1-2 kez, \%6,9'u 15 günde $1 \mathrm{kez}$, \%5,2'si ayda 1 kez ve \%29,3'ü hiç tüketmemektedir. Kırmızı et tüketenlerin $\% 5,2$ 'si her gün, \%17,2'si haftada 3-4 kez, $\% 43,1$ 'i haftada $1-2 \mathrm{kez}, \% 8,6$ 's 15 günde 1 kez, \%6,9'u ayda 1 kez ve \%19'u hiç tüketmemektedir. Balık tüketenlerin \%10,3'ü haftada 1-2 kez, \%22,4'ü 15 günde $1 \mathrm{kez}$ $\% 37,9$ 'u ayda $1 \mathrm{kez}$ ve \%29,3'ü hiç tüketmemektedir. Yumurta tüketenlerin $\% 43,1$ 'i her gün, \%12,1'i haftada 5-6 kez, \%10,3'ü haftada 3-4 kez, \%17,2'si haftada 1$2 \mathrm{kez}, \% 3,4$ 'ü 15 günde $1 \mathrm{kez}, \% 1,7$ 'si ayda 1 kez, \%12,1'i hiç tüketmemektedir. 
Tablo 4: Yaş Grupları ve Cinsiyete Göre Makro Besin Ögeleri ve Posa Alım Miktarları

\begin{tabular}{|c|c|c|c|c|c|c|c|}
\hline & Yaş & $\mathbf{n}$ & Cinsiyet & $\mathbf{X}^{*}$ & SD & Min & Max \\
\hline \multirow{6}{*}{ Enerji (kcal) } & $7-8$ yaş & 3 & $\mathrm{~K} 1 \mathrm{z}$ & 1261 & 234,6 & 992,0 & 1424,0 \\
\hline & & 9 & Erkek & 1151 & 134,1 & 926,0 & 1303,0 \\
\hline & 9-13 yaş & 4 & $\mathrm{~K} 1 \mathrm{z}$ & 1289 & 99,4 & 1186,0 & 1424,0 \\
\hline & & 31 & Erkek & 1377 & 255,4 & 922,0 & 1892,0 \\
\hline & 14 yaş & 3 & $\mathrm{~K} 1 \mathrm{z}$ & 1336 & 445,3 & 958,0 & 1827,0 \\
\hline & & 8 & Erkek & 1566 & 307,5 & 1222,0 & 2016,0 \\
\hline \multirow{6}{*}{ Protein (g) } & 7-8 Yaş & 3 & $\mathrm{~K}_{12}$ & 52,3 & 14,2 & 35,9 & 62,0 \\
\hline & & 9 & Erkek & 43,8 & 9,0 & 28,4 & 58,4 \\
\hline & 9-13 yaş & 4 & $\mathrm{~K}_{1 \mathrm{z}}$ & 54,2 & 26,4 & 35,0 & 93,3 \\
\hline & & 31 & Erkek & 53,2 & 12,8 & 24,0 & 79,6 \\
\hline & 14 yaş & 3 & $\mathrm{~K}_{1 \mathrm{z}}$ & 50,9 & 12,2 & 41,6 & 64,8 \\
\hline & & 8 & Erkek & 62,9 & 17,2 & 48,8 & 94,6 \\
\hline \multirow{6}{*}{ Protein \% } & 7-8 yaş & 3 & $\mathrm{~K}_{1 \mathrm{z}}$ & 17,0 & 1,7 & 15,0 & 18,0 \\
\hline & & 9 & Erkek & 15,5 & 1,8 & 13,0 & 18,0 \\
\hline & 9-13 yaş & 4 & $\mathrm{~K}_{1 \mathrm{z}}$ & 17,0 & 6,7 & 12,0 & 27,0 \\
\hline & & 31 & Erkek & 15,6 & 2,5 & 9,0 & 20,0 \\
\hline & 14 yaş & 3 & $\mathrm{~K}_{1 \mathrm{z}}$ & 16,0 & 1,7 & 15,0 & 18,0 \\
\hline & & 8 & Erkek & 16,5 & 2,5 & 12,0 & 20,0 \\
\hline \multirow{6}{*}{ Yağ (g) } & $7-8$ yaş & 3 & $\mathrm{~K}_{1 \mathrm{Z}}$ & 53,3 & 8,8 & 43,4 & 60,6 \\
\hline & & 9 & Erkek & 50,0 & 7,1 & 41,6 & 60,1 \\
\hline & 9-13 yaş & 4 & $\mathrm{~K}_{1 \mathrm{z}}$ & 67,6 & 5,3 & 62,0 & 74,8 \\
\hline & & 31 & Erkek & 63,5 & 14,6 & 41,0 & 102,0 \\
\hline & 14 yaş & 3 & $\mathrm{~K}_{1 \mathrm{Z}}$ & 65,2 & 28,7 & 42,3 & 97,5 \\
\hline & & 8 & Erkek & 73,1 & 18,8 & 55,2 & 102,2 \\
\hline \multirow{6}{*}{ Yağ \% } & $7-8$ yaş & 3 & $\mathrm{~K}_{1 \mathrm{z}}$ & 37,0 & 1,0 & 36,0 & 38,0 \\
\hline & & 9 & Erkek & 38,8 & 5,7 & 32,0 & 39,0 \\
\hline & 9-13 yaş & 4 & $\mathrm{~K}_{1 \mathrm{z}}$ & 46,7 & 6,6 & 42,0 & 56,0 \\
\hline & & 31 & Erkek & 41,0 & 5,0 & 30,0 & 54,0 \\
\hline & 14 yaş & 3 & $\mathrm{~K}_{1 \mathrm{Z}}$ & 42,0 & 4,3 & 39,0 & 47,0 \\
\hline & & 8 & Erkek & 41,0 & 3,9 & 36,0 & 48,0 \\
\hline \multirow{6}{*}{ Karbonhidrat (g) } & $7-8$ yaş & 3 & $\mathrm{~K}_{1 \mathrm{z}}$ & 141,2 & 24,1 & 113,3 & 156,0 \\
\hline & & 9 & Erkek & 124,2 & 34,8 & 45,5 & 160,3 \\
\hline & 9-13 yaş & 4 & $\mathrm{~K} 1 \mathrm{z}$ & 114,4 & 18,8 & 138,0 & 45,0 \\
\hline & & 31 & Erkek & 146,0 & 31,9 & 61,3 & 213,4 \\
\hline & 14 yaş & 3 & $\mathrm{~K} 1 \mathrm{z}$ & 134,9 & 34,7 & 101,6 & 170,8 \\
\hline & & 8 & Erkek & 160,9 & 31,4 & 115,3 & 201,0 \\
\hline \multirow{6}{*}{ Karbonhidrat \% } & $7-8$ yaş & 3 & $\mathrm{~K} 1 \mathrm{z}$ & 46,0 & 1,0 & 45,0 & 47,0 \\
\hline & & 9 & Erkek & 45,5 & 5,4 & 35,0 & 51,0 \\
\hline & $9-13$ yaş & 4 & $\mathrm{~K}_{12}$ & 36,2 & 6,0 & 31,0 & 44,0 \\
\hline & & 31 & Erkek & 43,3 & 6,2 & 27,0 & 54,0 \\
\hline & 14 yaş & 3 & $\mathrm{~K}_{1 \mathrm{z}}$ & 42,0 & 3,6 & 38,0 & 45,0 \\
\hline & & 8 & Erkek & 42,3 & 5,4 & 32,0 & 48,0 \\
\hline \multirow{6}{*}{ Posa (g) } & 7-8 yaş & 3 & $\mathrm{~K}_{1 \mathrm{z}}$ & 12,1 & 5,5 & 6,9 & 18,0 \\
\hline & & 9 & Erkek & 13,0 & 5,0 & 8,0 & 21,9 \\
\hline & 9-13 yaş & 4 & $\mathrm{~K} 1 \mathrm{z}$ & 13,5 & 3,8 & 7,7 & 16,3 \\
\hline & & 31 & Erkek & 14,1 & 3,1 & 8,1 & 19,9 \\
\hline & 14 yaş & 3 & $\mathrm{~K}_{1 \mathrm{z}}$ & 14,5 & 5,7 & 8,5 & 20,0 \\
\hline & & 8 & Erkek & 15,0 & 2,8 & 8,8 & 17,5 \\
\hline
\end{tabular}


Yemek yeme problemleri ile makro ve mikro besin ögelerinin alımı karşılaştırılmış ve istatistiksel olarak anlamlı bir fark olmadığ 1 görülmüştür $(p>0,05)$. Yiyecekleri renk, tat ve koku özelliklerine göre tercih etme durumu ile makro ve mikro besin ögelerinin alımı karşılaştırılmış ve istatistiksel olarak anlamlı bir ilişki bulunmamıştır $(\mathrm{p}>0,05)$.

MacDonald ve arkadaşlarının yaptığ 1 çalışmada otizmli çocukların yaşa bağlı olarak fiziksel aktivite düzeylerinde düşüşler gözlenmiştir. Çocuğun yaşı ilerledikçe fiziksel aktivite düzeyi düşmektedir. ${ }^{21}$ Curtin ve arkadaşlarının yaptığı çalışmada otizmli çocuklarda fazla kilolu çocukların oranı \%19 ve fazla kilolu olmanın en yaygın olduğu yaş grubu 12,0-17,9 olarak belirlenmiştir. ${ }^{22}$ Criado ve arkadaşlarının otizmli çocuklar üzerinde yaptığ 1 çalışmada, kilolu çocukların oranı $\% 42,4$ ve obez çocukların oranı $\% 21,4$ bulunmuştur. ${ }^{23} \mathrm{Bu}$ araştırmada ortalama BKI $23,6 \pm 5,2 \mathrm{~kg} / \mathrm{m}^{2}$ olduğu görülmüştür. Tablo 3 incelendiğinde BKİ ile yeni yiyecek denemeyi reddetme arasında anlamlı bir ilişki olduğu belirlenmiştir $(\mathrm{p}<0,05)$.

Otizmin merkezi sinir sistemi disfonksiyonu ile ilişkili olduğu ve epilepsinin otizm ile ilişkili olduğu düşünülmektedir. Otizmli çocukların üçte birinde epilepsi görüldüğü bildirilmiştir. $^{24}$ Canitona ve arkadaşlarının yaptığı çalışmada 46 otizmli çocuk incelenmiş ve çocukların \%13'ünde epilepsi olduğu gösterilmiştir. ${ }^{25} \mathrm{Bu}$ araştırmada çocukların \%12,1'inin epilepsi tanısı aldığı aileler tarafından bildirilmiştir.

GFCF diyeti, gluten ve kazein proteinlerinin yeterince parçalanamaması sonucu sistemik dolaşıma geçerek opioid etki gösterdiği gerekçesiyle otizmin tedavisinde kullanılmaktadır. Gluten ve kazeinin diyetten çıkarılması ile bu etkinin azalacağ düşünülmektedir. ${ }^{12,13}$ KD'nin ise otizm üzerindeki etki mekanizmasının glukozun azaltılması yoluyla ağrı duyarlılığının azalabileceği yönündedir. ${ }^{16}$

Graf-Myles ve arkadaşlarının yaptığı çalışmada otizmli 69 çocuktan 23 (\%33)'ünün diyet uyguladığı görülmüştür. Bunlardan 3'ü GF 5'i CF, 10'u GFCF ve 5'i GFCF+Soya diyetlerini uyguladığ 1 gösterilmiştir. İyi bir A vitamini, D vitamini, riboflavin, kalsiyum, fosfor kaynağı olan inek sütünün ve demir, tiamin, riboflavin, niasin ve folik asit ile zenginleştirilmiş tahıl ürünlerinin diyetten çıkarılması ile bu vitamin ve minerallerin yetersizliğinin görülmesi muhtemeldir. ${ }^{26} \mathrm{Bu}$ araştırmada ise $13(\% 22,3)$ çocuğun özel bir diyet uyguladığ 1 bildirilmiştir. $\mathrm{Bu}$ çocuklardan 5'inin GF, 6'sının GFCF, 1 'inin KD ve 1'inin GAPS diyetini uyguladiğ belirlenmiştir. Bu diyetlerin uygulanmasının yeme problemlerinin yaygın görüldüğ ü ve tat, koku gibi özelliklere karşı hassas olan otizmli çocuklarda besin seçiciliğinin ve besin reddinin artmasına da sebep olabileceği düşünülmektedir. ${ }^{12}$

OSB'li çocukların 1/3'inde GÖR, abdominal ağrı, diyare ve kabızlık gibi gastrointestinal problemler bildirilmiştir. ${ }^{7}$ Liu ve arkadaşlarının Çin'de yaptıkları bir çalışmada otizmli çocukların \%22,1'inde kabızlı problemi ve \%2,6'sinda ishal problemi olduğu görülmüştür. ${ }^{27}$ Çin'de yapılmış bir başka çalışmada Sun ve arkadaşları çocukların \%39,6'sında kabızlık problemi ve \%26,4'ünde ishal problemi olduğunu saptamıştır. ${ }^{28}$

Ferguson ve arkadaşlarının toplam 120 otizmli çocuk ile yaptığ 1 çalışmada fonksiyonel kabızlık oranının \%42,5 olduğu belirlenmiştir. Yine bu çalışmada kabızlık ve kabızlığa bağlı karın ağrısının, çocuklarda uyku problemleri ve anksiyete ile ilişkili olduğu saptanmıştır. ${ }^{29}$ Tablo 1'e göre bu araştırmada çocukların \%38,0'inde kabızlık, $\% 3,6$ 'sında ishal ve \%30,7'sinde şişkinlik ve gaz problemi olduğu belirlenmiştir.

OSB'li çocuklarda yeme problemlerinin yaygın olduğu görülmektedir. Bunların başında verilen besini ağızda tutma veya verilen besini geri çıkarma, verilen besini yemeyi reddetme gelmektedir. ${ }^{30}$

Yapılan bir çalışmada otizmli çocuklarda hafif yeme problemleri yaşayanların oranı $\% 37,7$ iken şiddetli yeme problemleri yaşayan çocukların oranı $\% 32,5$ bulunmuştur. ${ }^{27}$ 
Tablo 5. Yaş Grupları ve Cinsiyete Göre Vitamin ve Mineral Alım Miktarları

\begin{tabular}{|c|c|c|c|c|c|c|c|}
\hline & Yaş & $\mathbf{n}$ & Cinsiyet & $\mathbf{X}^{*}$ & SD & RDA & RDA\%** \\
\hline & $7-8$ yaş & 3 & $\mathrm{~K}_{1 \mathrm{z}}$ & 543,9 & 307,1 & 400 & 135 \\
\hline Vitamin & & 9 & Erkek & 740,7 & 502,5 & 400 & 185 \\
\hline \multirow[t]{5}{*}{$A(\mu g)$} & 9-13 yaş & 4 & $\mathrm{~K}_{1 \mathrm{Z}}$ & 770,0 & 256,7 & 600 & 128 \\
\hline & & 31 & Erkek & 728,3 & 528,6 & 600 & 121 \\
\hline & 14 yaş & 3 & $\mathrm{~K}_{1 \mathrm{Z}}$ & 752,2 & 238,6 & 700 & 107 \\
\hline & & 8 & Erkek & 790,8 & 310,7 & 900 & 87 \\
\hline & 7-8 Yaş & 3 & $\mathrm{~K}_{1 \mathrm{Z}}$ & 34,2 & 16,5 & 25 & 136 \\
\hline \multirow{6}{*}{$\begin{array}{l}\text { Vitamin } \\
\text { C (mg) }\end{array}$} & & 9 & Erkek & 54,4 & 32,6 & 25 & 216 \\
\hline & 9-13 yaş & 4 & $\mathrm{~K}_{1 \mathrm{z}}$ & 71,0 & 49,6 & 45 & 157 \\
\hline & & 31 & Erkek & 46,9 & 31,7 & 45 & 102 \\
\hline & 14 yaş & 3 & $\mathrm{~K}_{1 \mathrm{z}}$ & 63,3 & 49,7 & 65 & 96 \\
\hline & & 8 & Erkek & 64,2 & 57,8 & 75 & 85 \\
\hline & $7-8$ yaş & 3 & $\mathrm{~K}_{1 \mathrm{z}}$ & 11,1 & 0,9 & 7 & 157 \\
\hline \multirow{6}{*}{$\begin{array}{l}\text { Vitamin } \\
\text { E (mg) }\end{array}$} & & 9 & Erkek & 10,9 & 3,3 & 7 & 142 \\
\hline & 9-13 yaş & 4 & $\mathrm{~K}_{1 \mathrm{Z}}$ & 18,0 & 6,5 & 11 & 163 \\
\hline & & 31 & Erkek & 18,1 & 17,3 & 11 & 163 \\
\hline & 14 yaş & 3 & $\mathrm{~K}_{1 \mathrm{z}}$ & 13,3 & 3,7 & 15 & 86 \\
\hline & & 8 & Erkek & 14,5 & 2,9 & 15 & 93 \\
\hline & $7-8$ yaş & 3 & $\mathrm{~K}_{1 \mathrm{z}}$ & 0,5 & 0,0 & 0,6 & 85 \\
\hline \multirow{6}{*}{$\begin{array}{l}\text { Vitamin } \\
\text { B1 (mg) }\end{array}$} & & 9 & Erkek & 0,4 & 0,1 & 0,6 & 80 \\
\hline & 9-13 yaş & 4 & $\mathrm{~K}_{1 \mathrm{z}}$ & 0,5 & 0,6 & 0,9 & 63 \\
\hline & & 31 & Erkek & 0,5 & 0,1 & 0,9 & 62 \\
\hline & 14 yaş & 3 & $\mathrm{~K}_{1 \mathrm{Z}}$ & 0,5 & 0,2 & 1,0 & 56 \\
\hline & & 8 & Erkek & 0,6 & 0,1 & 1,2 & 57 \\
\hline & $7-8$ yaş & 3 & $\mathrm{~K}_{1 \mathrm{Z}}$ & 0,9 & 0,2 & 0,6 & 156 \\
\hline \multirow{5}{*}{$\begin{array}{l}\text { Vitamin } \\
\text { B2 (mg) }\end{array}$} & & 9 & Erkek & 0,8 & 0,2 & 0,6 & 141 \\
\hline & 9-13 yaş & 4 & $\mathrm{~K}_{1 \mathrm{z}}$ & 1,0 & 0,2 & 0,9 & 112 \\
\hline & & 31 & Erkek & 0,9 & 0,3 & 0,9 & 110 \\
\hline & 14 yaş & 3 & $\mathrm{~K}_{1 \mathrm{z}}$ & 0,8 & 0,3 & 1,0 & 89 \\
\hline & & 8 & Erkek & 1,4 & 0,6 & 1,3 & 111 \\
\hline Vitamin & $7-8$ yaş & 3 & $\mathrm{~K}_{1 \mathrm{z}}$ & 0,7 & 0,0 & 0,6 & 130 \\
\hline \multirow[t]{5}{*}{ B6 (mg) } & & 9 & Erkek & 0,8 & 0,1 & 0,6 & 140 \\
\hline & $9-13$ yaş & 4 & $\mathrm{~K}_{1 \mathrm{Z}}$ & 0,8 & 0,2 & 1,0 & 87 \\
\hline & & 31 & Erkek & 0,9 & 0,3 & 1,0 & 90 \\
\hline & 14 yaş & 3 & $\mathrm{~K}_{1 \mathrm{z}}$ & 1,0 & 0,3 & 1,2 & 84 \\
\hline & & 8 & Erkek & 1,0 & 0,2 & 1,3 & 79 \\
\hline \multirow{7}{*}{$\begin{array}{l}\text { Folat } \\
(\mu \mathrm{g})\end{array}$} & $7-8$ yaş & 3 & $\mathrm{~K}_{1 \mathrm{z}}$ & 162,4 & 14,5 & 200 & 81 \\
\hline & & 9 & Erkek & 159,3 & 39,6 & 200 & 79 \\
\hline & $9-13$ yaş & 4 & $\mathrm{~K}_{1 \mathrm{Z}}$ & 176,7 & 40,1 & 300 & 88 \\
\hline & & 31 & Erkek & 182,3 & 50,6 & 300 & 60 \\
\hline & 14 yaş & 3 & $\mathrm{~K}_{1 \mathrm{z}}$ & 189,3 & 54,3 & 400 & 47 \\
\hline & & 8 & Erkek & 224,9 & 51,2 & 400 & 56 \\
\hline & $7-8$ yaş & 3 & $\mathrm{~K}_{1 \mathrm{Z}}$ & 439,3 & 152,2 & 1000 & 44 \\
\hline \multirow{5}{*}{$\begin{array}{l}\text { Kalsiyum } \\
\text { (mg) }\end{array}$} & & 9 & Erkek & 463,7 & 192,0 & 1000 & 46 \\
\hline & 9-13 yaş & 4 & $\mathrm{~K}_{1 \mathrm{z}}$ & 586,4 & 134,8 & 1300 & 45 \\
\hline & & 31 & Erkek & 533,4 & 240,0 & 1300 & 41 \\
\hline & 14 yaş & 3 & $\mathrm{~K}_{1 z}$ & 533,7 & 211,9 & 1300 & 41 \\
\hline & & 8 & Erkek & 723,2 & 129,1 & 1300 & 55 \\
\hline
\end{tabular}


Tablo 5. ( Devamı) Yaş Grupları ve Cinsiyete Göre Vitamin ve Mineral Alım Miktarları

\begin{tabular}{|c|c|c|c|c|c|c|c|}
\hline & $7-8$ yaş & 3 & $\mathrm{~K}_{1 \mathrm{z}}$ & 175,9 & 24,8 & 130 & 134 \\
\hline \multirow{5}{*}{$\begin{array}{l}\text { Magnezyum } \\
\text { (mg) }\end{array}$} & & 9 & Erkek & 167,1 & 47,5 & 130 & 128 \\
\hline & $9-13$ yaş & 4 & $\mathrm{~K}_{1 \mathrm{Z}}$ & 200,4 & 39,8 & 240 & 83 \\
\hline & & 31 & Erkek & 190,6 & 52,9 & 240 & 79 \\
\hline & 14 yaş & 3 & $\mathrm{~K}_{1 z}$ & 213,6 & 69,9 & 360 & 59 \\
\hline & & 8 & Erkek & 220,7 & 36,2 & 410 & 54 \\
\hline \multirow{6}{*}{$\begin{array}{l}\text { Fosfor } \\
\text { (mg) }\end{array}$} & 7-8 yaş & 3 & $\mathrm{~K}_{1 \mathrm{Z}}$ & 780,2 & 169,2 & 500 & 156 \\
\hline & & 9 & Erkek & 747,0 & 194,6 & 500 & 149 \\
\hline & $9-13$ yaş & 4 & $\mathrm{~K}_{1 z}$ & 868,9 & 288,1 & 1250 & 69 \\
\hline & & 31 & Erkek & 855,0 & 222,1 & 1250 & 68 \\
\hline & 14 yaş & 3 & $\mathrm{~K}_{1 \mathrm{z}}$ & 866,1 & 238,1 & 1250 & 69 \\
\hline & & 8 & Erkek & 1056,0 & 109,0 & 1250 & 84 \\
\hline \multirow{6}{*}{$\begin{array}{l}\text { Demir } \\
\text { (mg) }\end{array}$} & $7-8$ yaş & 3 & $\mathrm{~K}_{1 \mathrm{Z}}$ & 8,2 & 1,9 & 10 & 82 \\
\hline & & 9 & Erkek & 6,9 & 2,6 & 10 & 70 \\
\hline & $9-13$ yaş & 4 & $\mathrm{~K}_{12}$ & 8,1 & 1,8 & 8 & 102 \\
\hline & & 31 & Erkek & 9,6 & 10,1 & 8 & 120 \\
\hline & 14 yaş & 3 & $\mathrm{~K}_{1 \mathrm{z}}$ & 8,1 & 2,9 & 15 & 55 \\
\hline & & 8 & Erkek & 9,4 & 2,5 & 11 & 85 \\
\hline \multirow{6}{*}{$\begin{array}{l}\text { Çinko } \\
\text { (mg) }\end{array}$} & $7-8$ yaş & 3 & $\mathrm{~K}_{1 \mathrm{Z}}$ & 7,3 & 1,9 & 5 & 147 \\
\hline & & 9 & Erkek & 5,9 & 1,4 & 5 & 118 \\
\hline & $9-13$ yaş & 4 & $\mathrm{~K}_{1 \mathrm{Z}}$ & 7,2 & 2,7 & 8 & 91 \\
\hline & & 31 & Erkek & 7,3 & 1,9 & 8 & 91 \\
\hline & 14 yaş & 3 & $\mathrm{~K}_{1 \mathrm{z}}$ & 7,0 & 2,0 & 9 & 78 \\
\hline & & 8 & Erkek & 8,7 & 2,2 & 11 & 79 \\
\hline \multirow{6}{*}{$\begin{array}{l}\text { Sodyum } \\
\text { (mg) }\end{array}$} & $7-8$ yaş & 3 & $\mathrm{~K}_{12}$ & 1786 & 771,9 & 1900 & 94 \\
\hline & & 9 & Erkek & 2102 & 530,8 & 1900 & 110 \\
\hline & $9-13$ yaş & 4 & $\mathrm{~K}_{1 \mathrm{z}}$ & 1950 & 423,5 & 2300 & 85 \\
\hline & & 31 & Erkek & 2657 & 642,9 & 2300 & 115 \\
\hline & 14 yaş & 3 & $\mathrm{~K}_{1 Z}$ & 2487 & 782,5 & 2300 & 109 \\
\hline & & 8 & Erkek & 2650 & 611,9 & 2300 & 115 \\
\hline \multirow{6}{*}{$\begin{array}{l}\text { Potasyum } \\
\text { (mg) }\end{array}$} & $7-8$ yaş & 3 & $\mathrm{~K}_{1 \mathrm{Z}}$ & 1421 & 168,4 & 3800 & 37 \\
\hline & & 9 & Erkek & 1518 & 372,2 & 3800 & 40 \\
\hline & $9-13$ yaş & 4 & $\mathrm{~K}_{1 \mathrm{z}}$ & 1654 & 445,8 & 4500 & 37 \\
\hline & & 31 & Erkek & 1615 & 689,0 & 4500 & 36 \\
\hline & 14 yaş & 3 & $\mathrm{~K}_{1 \mathrm{Z}}$ & 1624 & 585,0 & 4700 & 35 \\
\hline & & 8 & Erkek & 2046 & 464,3 & 4700 & 44 \\
\hline
\end{tabular}

Bir başka çalışmada ise yeni yiyecek denemeyi reddedenlerin oran $\%$ 63,3 olarak belirlenmiştir. $^{28} \mathrm{Bu}$ araştırmada ise yeni yiyecek denemeyi reddedenlerin oran $\% 46,4$ besinleri ağızda tutma $\% 8,2$ verilen besini geri çıkarma $\% 8,2$ ve çiğneme güçlüğü $\% 6,6$ olarak bulunmuştur. Otizmli çocukların yiyecekleri renk, tat, koku, isı ve doku özelliklerine göre seçici davrandığı ve yiyeceği reddettiği görülmektedir. $\mathrm{Bu}$ davranışların otizmli çocuklarda bulunan takıntılı, sınırlı ve tekrarlayıcı davranışlar ile ilişkili olabileceği öne sürülmektedir. ${ }^{30}$ Hubbard ve arkadaşlarının yaptığ 1 çalışmada otizmli çocukların sağlıklı kontrollere kıyasla daha fazla yiyecek reddettiği görülmüştür. Özellikle yiyeceği rengine göre reddetme $\% 15,1$ iken yiyeceği tat ve koku özelliklerine göre reddetme $\% 49,1$ olarak belirlenmiştir. ${ }^{31}$

Nadon ve arkadaşlarının yaptığ çalışmada otizmli çocukların yiyeceklerin dokusuna, sıcaklığına, tat ve kokusuna önemli ölçüde hassasiyet gösterdikleri saptanmıştır. Toplam tükettiği yiyecek sayısı 20'nin altında olan 
çocuklarda yemek yeme problemlerinin daha yaygın olduğu görülmüştür. Bununla birlikte çocuğun görsel ve işitsel duyarlılığının, yemek yeme problemleriyle ilişkili olduğu belirlenmiştir. ${ }^{32} \mathrm{Bu}$ araştırmanın sonucuna göre çocukların \%22,3'ünün yiyecekleri rengine göre reddettiği, \%14,6'sının tat özelliklerine göre reddettiği ve \%40,8'inin koku özelliklerine göre yiyeceği reddettiği tespit edilmiştir. Meguid ve arkadaşlarının yaptığı çalışmada otizmli çocukların 3 günlük besin tüketim kayıtları alınarak günlük besin alımları hesaplanmıştır. Buna göre; protein ve yağ alımlarının yüksek iken posa alımlarının yeterli olduğu görülmüştür. $C$ vitamini ve kalsiyum alımları düşük bulunmuştur. Özellikle 6-9 yaş arası çocuklarda folat ve çinko düzeylerinin çok düşük olduğu görülmüştür. ${ }^{33}$

Hyman ve arkadaşlarının yaptığı çalışmada 3 günlük besin tüketim kayıtları alınan çocuklarda lif alımlarının çok düşük olduğu, potasyum alımlarının yetersiz olduğu ve sodyum alımlarının önerilen miktarlardan yüksek olduğu belirlenmiştir. 4-8 yaş arası çocuklarda A vitamini, C vitamini ve çinko alımlarının yetersiz olduğu, 9-11 yaş grubunda ise fosfor alımının yetersiz olduğu gözlenmiştir. ${ }^{34}$ Tablo 4'e göre bu araştırmada, yaş grupları ve cinsiyete göre RDA'nın önerdiği miktarlar göz önüne alındığında protein alımının yüksek, posa alımının çok düşük olduğu görülmüştür. Tablo 5 incelendiğinde ise vitamin B1, B6, folat, kalsiyum ve potasyum alımlarının önerilen miktarlardan çok düşük olduğu belirlenmiştir. 9-14 yaş gruplarında magnezyum, fosfor ve çinko, 14 yaş grubunda vitamin $\mathrm{C}$ ile vitamin E alımının yetersiz olduğu görülmüştür. Demir alımının ise 7-8 yaş grubu ile 14 yaş grubunda yetersiz olduğu saptanmıştır. Tablo 6 incelendiğinde çocukların, süt, yoğurt, kırmızı et, balık, yeşil yapraklı sebzeler gibi temel besinleri hiç tüketmediği görülmüştür.

Tablo 6. Besinlerin Tüketim Sıklığının Belirlenmesi

\begin{tabular}{|c|c|c|c|c|c|c|c|c|c|c|c|c|c|c|c|c|}
\hline \multirow[t]{2}{*}{ Besin ve besin grupları } & \multicolumn{2}{|c|}{ Her gün } & \multicolumn{2}{|c|}{$\begin{array}{c}\text { Haftada 5- } \\
6 \\
\end{array}$} & \multicolumn{2}{|c|}{$\begin{array}{c}\text { Haftada } \\
3-4 \\
\end{array}$} & \multicolumn{2}{|c|}{$\begin{array}{c}\text { Haftada } \\
1-2 \\
\end{array}$} & \multicolumn{2}{|c|}{15 günde 1} & \multicolumn{2}{|c|}{ Ayda 1} & \multicolumn{2}{|c|}{ Hiç } & \multicolumn{2}{|c|}{ Toplam } \\
\hline & n & $\%$ & $\mathbf{n}$ & $\%$ & $\mathbf{n}$ & $\%$ & $\mathbf{n}$ & $\%$ & $\mathbf{n}$ & $\%$ & $\mathbf{n}$ & $\%$ & n & $\%$ & $\mathbf{n}$ & $\%$ \\
\hline Süt & 17 & 29,3 & 5 & 8,6 & 5 & 8,6 & 7 & 12,1 & 4 & 6,9 & 3 & 5,2 & 17 & 29,3 & 58 & 100,0 \\
\hline Yoğurt & 17 & 29,3 & 7 & 12,1 & 9 & 15,5 & 4 & 6,9 & 5 & 8,6 & 4 & 6,9 & 12 & 20,7 & 58 & 100,0 \\
\hline Peynir & 17 & 32,8 & 6 & 10,3 & 7 & 12,1 & 9 & 15,5 & 2 & 3,4 & 2 & 3,4 & 13 & 22,4 & 58 & 100,0 \\
\hline Ayran & 12 & 20,7 & 8 & 13,8 & 8 & 13,8 & 10 & 17,2 & 5 & 8,6 & 1 & 1,7 & 14 & 24,1 & 58 & 100,0 \\
\hline Kefir & 2 & 3,4 & 1 & 1,7 & 3 & 5,2 & 0 & 0 & 0 & 0 & 0 & 0 & 52 & 89,7 & 58 & 100,0 \\
\hline Kırmızı Et & 3 & 5,2 & 0 & 0 & 10 & 17,2 & 25 & 43,1 & 5 & 8,6 & 4 & 6,9 & 11 & 19,0 & 58 & 100,0 \\
\hline Tavuk & 6 & 10,3 & 3 & 5,2 & 13 & 22,4 & 23 & 39,7 & 7 & 12,1 & 4 & 6,9 & 2 & 3,4 & 58 & 100,0 \\
\hline Balık & 0 & 0 & 0 & 0 & 0 & 0 & 6 & 10,3 & 13 & 22,4 & 17 & 37,9 & 22 & 29,3 & 58 & 100,0 \\
\hline Yumurta & 25 & 43,1 & 7 & 12,1 & 6 & 10,3 & 10 & 17,2 & 2 & 3,4 & 1 & 1,7 & 7 & 12,1 & 58 & 100,0 \\
\hline Kurubaklagil & 4 & 6,9 & 5 & 8,6 & 12 & 20,7 & 31 & 53,4 & 5 & 8,6 & 0 & 0 & 1 & 1,7 & 58 & 100,0 \\
\hline $\begin{array}{l}\text { Findık,Fistık,Ceviz, } \\
\text { Badem Gibi Çerez }\end{array}$ & 15 & 25,9 & 8 & 13,8 & 9 & 15,5 & 14 & 24,1 & 5 & 8,6 & 1 & 1,7 & 6 & 10,3 & 58 & 100,0 \\
\hline Yeşil Yapraklı Sebzeler & 9 & 15,5 & 1 & 1,7 & 16 & 27,6 & 11 & 19,0 & 2 & 3,4 & 2 & 3,4 & 17 & 29,3 & 58 & 100,0 \\
\hline Diğer Sebzeler & 3 & 5,2 & 2 & 3,4 & 8 & 13,8 & 15 & 25,9 & 8 & 13,8 & 3 & 5,2 & 19 & 32,8 & 58 & 100,0 \\
\hline Patates & 8 & 13,8 & 6 & 10,3 & 20 & 34,5 & 20 & 34,5 & 1 & 1,7 & 2 & 3,4 & 1 & 1,7 & 58 & 100,0 \\
\hline Turunçgiller & 5 & 8,6 & 4 & 6,9 & 16 & 27,6 & 15 & 25,9 & 3 & 5,2 & 1 & 1,7 & 14 & 24,1 & 58 & 100,0 \\
\hline Kuru Meyveler & 4 & 6,9 & 5 & 8,6 & 4 & 6,9 & 10 & 17,2 & 10 & 17,2 & 2 & 3,4 & 23 & 39,7 & 58 & 100,0 \\
\hline Beyaz Ekmek & 41 & 70,7 & 3 & 5,2 & 3 & 5,2 & 3 & 5,2 & 0 & 0 & 0 & 0 & 8 & 13,8 & 58 & 100,0 \\
\hline Tam Tahıllı Ekmek & 10 & 17,2 & 1 & 1,7 & 4 & 6,9 & 4 & 6,9 & 2 & 3,4 & 0 & 0 & 37 & 63,8 & 58 & 100,0 \\
\hline Pirinç Pilavı & 3 & 5,2 & 7 & 12,1 & 12 & 20,7 & 15 & 25,9 & 6 & 10,3 & 4 & 6,9 & 11 & 19,0 & 58 & 100,0 \\
\hline Bulgur Pilavı & 2 & 3,4 & 3 & 5,2 & 10 & 17,2 & 16 & 27,6 & 6 & 10,3 & 4 & 6,9 & 17 & 29,3 & 58 & 100,0 \\
\hline Makarna & 4 & 6,9 & 7 & 12,1 & 13 & 22,4 & 20 & 34,5 & 10 & 17,2 & 0 & 0 & 4 & 6,9 & 58 & 100,0 \\
\hline Bisküvi,Kraker & 14 & 24,1 & 13 & 22,4 & 11 & 19,0 & 15 & 25,9 & 3 & 5,2 & 1 & 1,7 & 1 & 1,7 & 58 & 100,0 \\
\hline Kahvaltılık Tahıllar & 7 & 12,1 & 1 & 1,7 & 2 & 3,4 & 4 & 6,9 & 1 & 1,7 & 1 & 1,7 & 42 & 72,4 & 58 & 100,0 \\
\hline Hazır Meyve Suları & 8 & 13,8 & 2 & 3,4 & 8 & 13,8 & 16 & 27,6 & 10 & 17,2 & 3 & 5,2 & 11 & 19,0 & 58 & 100,0 \\
\hline Gazlı İçecekler & 2 & 3,4 & 2 & 3,4 & 2 & 3,4 & 4 & 6,9 & 4 & 6,9 & 11 & 19,0 & 33 & 56,9 & 58 & 100,0 \\
\hline Çay & 20 & 34,5 & 5 & 8,6 & 4 & 6,9 & 5 & 8,6 & 3 & 5,2 & 3 & 5,2 & 18 & 31,0 & 58 & 100,0 \\
\hline Kahve & 2 & 3,4 & 0 & 0 & 1 & 1,7 & 2 & 3,4 & 3 & 5,2 & 2 & 3,4 & 48 & 82,8 & 58 & 100,0 \\
\hline $\begin{array}{l}\text { Bal,Reçel,Pekmez, } \\
\text { Marmelat }\end{array}$ & 9 & 15,5 & 7 & 12,1 & 8 & 13,8 & 7 & 12,1 & 1 & 1,7 & 4 & 6,9 & 22 & 37,9 & 58 & 100,0 \\
\hline Şekerleme,Çikolata & 9 & 15,5 & 11 & 19,0 & 11 & 19,0 & 16 & 27,6 & 5 & 8,6 & 4 & 6,9 & 2 & 3,4 & 58 & 100,0 \\
\hline Cips & 4 & 6,9 & 2 & 3,4 & 7 & 12,1 & 19 & 32,8 & 11 & 19,0 & 2 & 3,4 & 13 & 22,4 & 58 & 100,0 \\
\hline Sütlü Tatlılar & 1 & 1,7 & 0 & 0 & 0 & 0 & 24 & 41,4 & 14 & 24,1 & 6 & 10,3 & 13 & 22,4 & 58 & 100,0 \\
\hline Şerbetli Tatlılar & 0 & 0 & 0 & 0 & 1 & 1,7 & 3 & 5,2 & 22 & 37,9 & 12 & 20,7 & 20 & 34,5 & 58 & 100,0 \\
\hline Zeytinyağı & 9 & 15,5 & 3 & 5,2 & 5 & 8,6 & 5 & 8,6 & 5 & 8,6 & 1 & 1,7 & 30 & 51,7 & 58 & 100,0 \\
\hline Diğer Sıvıyağlar & 25 & 43,1 & 11 & 19,0 & 6 & 10,3 & 8 & 13,8 & 2 & 3,4 & 0 & 0 & 6 & 10,3 & 58 & 100,0 \\
\hline Tereyağı & 12 & 20,7 & 6 & 10,3 & 9 & 15,5 & 12 & 20,7 & 3 & 5,2 & 1 & 1,7 & 15 & 25,9 & 58 & 100,0 \\
\hline
\end{tabular}




\section{SONUÇ VE ÖNERÍLER}

$\mathrm{Bu}$ araștırma Bağcilar Lokman Hekim Özel Eğitim ve Uygulama Merkezi'nde öğrenim gören 7-14 yaş arası OSB'li çocukların beslenme durumlarının belirlenmesi amacıyla yapılmıştır. Araştırmaya 10 kız 48 erkek olmak üzere toplam 58 otizmli çocuk katılmıştır.

Çocuklarda kabızlık ile şişkinlik ve gaz problemleri en s1k görülen gastrointestinal sorunlardır. Araştırmaya katılan çocuklarda yemek yeme ile ilgili problemler görülmüştür. Özellikle yeni yiyecek denemeye karşı direnç oldukça yaygındır. Çocukların yiyecekleri renk, tat, koku özelliklerine göre tercih ettiği de belirlenmiştir. BKİ ile yeni yiyecek denemeyi reddetme ve BKİ ile yiyecekleri renk, tat, koku özelliklerine göre tercih etme durumu arasında anlamlı bir ilişki olduğu görülmüştür. Konstipasyon ile yeni yiyecek denemeyi reddetme arasında da anlamlı bir ilişki saptanmıştır. Sebze ve meyve tüketiminin sinırlı olması dolayısıyla posa alımının da yetersiz olması bu çocuklarda konstipasyon sorunlarının artmasına sebebiyet verebilir.

Besin tüketim kayıtları incelendiğinde protein alımlarının yüksek, posa alımlarının ise düşük olduğu belirlenmiştir. Vitamin B1, B6, folat, kalsiyum ve potasyum alımlarının yetersiz olduğu belirlenmiştir. 9-14 yaş gruplarında magnezyum, fosfor ve çinko, 14 yaş grubunda vitamin $\mathrm{C}$ ile vitamin $\mathrm{E}$ alımının yetersiz olduğu görülmüştür. Çocuklarda görülen yetersiz vitamin ve mineral alımı büyüme ve gelişmeyi olumsuz etkileyen faktörlerdendir. Özellikle düşük kalsiyum ve fosfor kemik gelişimini olumsuz etkileyebilir. Antioksidan vitaminlerden $C$ ve $E$ vitaminin yetersiz alımı bağışıklık sistemi için risk oluşturabilir.

Nörogelişimsel bir bozukluk olan, yaygınlığı giderek artan ve yaşam boyu etkilerini gösteren OSB'nin tedavi sürecinde beslenme durumu önemli yer tutmaktadır. Özellikle otizm ile birlikte ortaya çıkan gastrointestinal sorunlar, yiyecek seçiciliği, takıntılı yeme davranışları ve uygulanan özel diyetler çocukların beslenme düzenini etkilemekte ve besin ögesi yetersizliklerine sebep olabilmektedir. Bu problemlerin hem çocuğun hem de ailenin yaşam kalitesini olumsuz etkileyeceği unutulmamalıdır.

Tanı alan çocukların diyetisyene yönlendirilmesi, bu sorunların çözülmesi ve tedavi süreci için önem arz etmektedir. Erken çocukluk döneminde yapılan doğru müdahaleler, çocuğun sindirim sistemi problemlerinin ve takintıli yeme davranışlarının çözülmesinde anahtar rol oynayabilmektedir. Takıntılı yeme davranışlarının çözümü ileride oluşabilecek vitamin ve mineral yetersizliklerinin de önüne geçilmesine olanak sağlar. Bu sebeple otizm ve beslenme ilişkisi daha ayrıntılı incelenerek, daha çok araştırma yapılmalı ve çözüm önerileri geliştirilmelidir.

KAYNAKLAR

1. Rakap S, Birkan B, Kalkan S. (2017). "Türkiye'de Otizm Spektrum Bozukluğu ve Otizm”. Rakap S. (Ed.). İstanbul.

2. Wolff S. (2004). "The History of Autism" Eur Child Adolesc Psychiatry,13, 201-208.

3. Cook KA, Willmerdinger AN. (2015). "The History of Autism",

4. Baker JP. (2013). “Autism at 70-Redrawing the Boundaries" N Engl J Med, 369 (12), 1089-1091.

5. CDC. (2018). “Autism Spectrum Disorder" https://www.cdc.gov/ncbddd/autism/data.html

6. Şener EF, Özkul Y. (2013). “Otizmin Genetik Temelleri” Sağlık Bilimleri Dergisi, 22 (1), 86-92.

7. Navarro F, Liu Y, Rhoads JM. (2016). "Can Probiotics Benefit Children with Autism Spectrum Disorders?" World J Gastroenterol, 22 (46), 10093-10102.
8. Furuta GT, Williams K, Kooros K, Kaul A, Panzer R, Coury DL Fuchs G. (2012). "Management of Constipation Children and Adolescent with Autism Spectrum Disorders" Pediatrics, 130, 98-105.

9. Aydın A, Kınacı C. (2016). “Otizme Çözüm Var!”. İstanbul: Hayygrup Yayınevi.

10. Fujiwara T, Morisaki N, Honda Y, Sampei M, Tani Y. (2016). "Chemicals Nutrition and Autism Spectrum Disorder: A Mini Review” Neurosci, 10 (174).

11. Millward C, Ferriter M, Calve SJ, Connel-Jones GG. (2008). "Gluten anda Casein Free Diets for Autistic Spectrum Disorder" Cochrane Database Syst Rev, 16 (2).

12. Bilgiç A, Cöngöloğlu A. (2009). "Otizm Spektrum Bozukluklarında Biyolojik Temelli Tamamlayıcı ve Alternatif Tıp Uygulamaları" Çocuk ve Gençlik Ruh Sağlığı Dergisi, 16 (3). 
13. Uçar K, Samur G. (2017). "Otizmin Tedavisinde Güncel Beslenme Tedavisi Yaklaşımları” Bes Diy Derg, 45 (1), 53-60.

14. Ly V, Bottelier M, Hoekstra PJ, Vasquez AA, Buitelaar JK, Rommelse NN. (2017). "Elimination Diets' Efficacy and Mechanisms in Attention Deficit Hyperactivity Disorder and Autism Spectrum Disorder" Eur Child Adolesc Pscyhiatry, 26, 1067-1079.

15. Elder JH, Kreider CM, Schaefer NM, Laosa MB. (2015). “A Review of Gluten and Casein Free Diets for Treatment of Autism: 2005-2015" Nutr Diet Suppl, 7, 87-101.

16. Bostock E, Kirkby KC, Taylor B. (2017). "The Current Status of the Ketogenic Diet in Psychiatry" Front Psychiatry, 8, 43.

17. Ünal G, Özenoğlu A. (2016). "Nörogelişimsel Bozukluklarda Beslenme" Clin Exp Health Sci, 6 (2), 80-85.

18. Kurt E, Örün E. "Yeme Bozukluğu Olan Çocuğa Yaklaşım" (2016). J Curr Pediatr, 14, 129-35.

19. Bilgiç A. (2012) "Otizm Spektrum Bozuklukları” Karabekiroğlu K. (Ed.). Bebek ve Ruh Sağlığı Temel Kitabı. (459-480). Türkiye Çocuk ve Genç Psikiyatri Derneği Yayınları.

20. Görmez A, Kırpınar İ. "Otizm Spektrum Bozuklukları: Erişkinlikte Değişim ve Psikiyatrik Eştanılar”, Yeni Symposium, 2015, 53 (4); 27-32.

21. MacDonald M, Esposito P, Ulrich D. (2011). "The Physical Activity Patterns of Children with Autism" Research Notes, 4, 422

22. Curtin C, Bandini LG, Perrin EC, Taybor TJ, Must A. (2005). "Prevelance of Overweight in Children and Adolecents with Attention Deficit Hyperactivity Disorder and Autism Spectrum Disorders: A Chart Rewiev" Pediatrics, 5(48), 1471-2431.

23. Criado KK, Sharp WG, McCracken CE ve ark. (2018) "Overweight and Obese Status in Children with Autism Spectrum Disorder and Distruptive Behavior" Autism, 22 (4), $450-459$

24. Lee H, Kang HC, Kim SW, Kim YK, Chung HJ. (2011) "Characteristics of Late-onset Epilepsy and EEG Findings in Children with Autism Spectrum Disorders" Korean J Pediatr, 54 (1), 22-28.
25. Canitano R, Luchetti A, Zappella M. (2005). "Epilepsy, Electroencephalographic Abnormalities and Regression in Children with Autism" J Child Neurol, 20 (1), 27-31.

26. Graf-Myles J, Farmer C, Thurm A, Royster C, Kahn P, Soskey L, Rohtschild L, Swedo S. (2013). "Dietary Aduquacy of Children with Autism Compared to Controls and the Impact to Restiricted Diet" J Dev Behav Pediatr, 34 (7).

27. Liu X, Liu J, Xiong X, Yang T, Hou N, Liang X, Chen J, Li T. (2016). "Correlation Between Nutrition and Symptoms: Nutritional Survey of Children with Autism Spectrum Disorder in Chongqing, China" Nutrients, 8, 294.

28. Sun C, Xia W, Zhao Y, Li N, Zhao D, Wu L. (2013). "Nutritional Status Survey of Children Autism and Typically Developing Children Aged 4-6 years in Heilongjiang Province, China" Journal of Nutritional Science, 2 (16), 1-8

29. Ferguson BJ, Marler S, Altstein LL ve ark. (2017) "Psychophysiological Associations with Gastrointestinal Symptomatology in Autism Spectrum Disorder" Autism Res, 10 (2), 276-288

30. Meral BF. (2017). "Otizm spektrum bozukluğu olan çocuklarda beslenme problemleri ve bilimsel dayanıklı davranışsal müdahaleler" Ankara Üniversitesi Eğitim Bilimleri Fakültesi Özel Eğitim Dergisi, 18, 1-16.

31. Hubbard KL, Anderson SE, Curtin C, Must A, Bandini LG (2014). "A Comparison of Food Refusal Related to Characteristics of Food in Children with Autism Spectrum Disorder and Typically Developing Children" J Acad Nutr Diet, 114 (12), 1981-87.

32. Nadon G, Feldman DE, Dunn W, Gisel E. (2011). “Association of Sensory Processing and Eating Problems in Children with Autism Spectrum Disorder", Autism Research and Tereatment.

33. Meguid N, Anwar N, Zaki S, Kandeel W, Ahmed N, Tewfik I. (2015). "Dietary Patterns of Children with Autism Spectrum Disorder: A Study Based in Egypt” Maced J Med Sci, 3 (2), 262267.

34. Hyman SL, Stewart PA, Schmidt B ve ark. (2012). "Nutrient Intake From Food in Children with Autism" Pediatrics, 130 (2), 145-153. 